\title{
Correction: Population pharmacokinetics of fludarabine in patients with aplastic anemia and Fanconi anemia undergoing allogeneic hematopoietic stem cell transplantation
}

\author{
E. Mohanan ${ }^{1}$ - J. C. Panetta ${ }^{2}$ - K. M. Lakshmi ${ }^{1}$ - E. S. Edison ${ }^{1} \cdot$ A. Korula ${ }^{1}$ - N. A. Fouzia ${ }^{1}$ A. Abraham ${ }^{1} \cdot$ \\ A. Viswabandya ${ }^{1} \cdot$ V. Mathews ${ }^{1} \cdot$ B. George ${ }^{1} \cdot$ A. Srivastava ${ }^{1} \cdot$ P. Balasubramanian ${ }^{1}$
}

Published online: 22 August 2018

(c) Macmillan Publishers Limited, part of Springer Nature 2018. This article is published with open access

Correction to: Bone Marrow Transplantation https://doi. org/10.1038/bmt.2017.79; Article published online 8 May 2017.

This article was originally published under a CC BYNC-ND 4.0 license, but has now been made available under a CC BY 4.0 license. The PDF and HTML versions of the article have been modified accordingly.

P. Balasubramanian

bpoonkuzhali@cmcvellore.ac.in

1 Department of Hematology, Christian Medical College,

Vellore, India

2 Department of Pharmaceutical Sciences, St. Jude Children's Research Hospital, Memphis, TN, USA
Open Access This article is licensed under a Creative Commons Attribution 4.0 International License, which permits use, sharing, adaptation, distribution and reproduction in any medium or format, as long as you give appropriate credit to the original author(s) and the source, provide a link to the Creative Commons license, and indicate if changes were made. The images or other third party material in this article are included in the article's Creative Commons license, unless indicated otherwise in a credit line to the material. If material is not included in the article's Creative Commons license and your intended use is not permitted by statutory regulation or exceeds the permitted use, you will need to obtain permission directly from the copyright holder. To view a copy of this license, visit http://creativecommons. org/licenses/by/4.0/. 